\title{
Peningkatan hasil belajar KPK dan FPB dengan pendekatan konstruktivisme
}

\section{Sabri Sabri}

SDN 12 Sungai Liku Kecamatan Ranah Pesisir Kab. Pesisir Selatan

\begin{tabular}{l} 
Article Info \\
\hline Article history: \\
Received Jul $18^{\text {th }}, 2020$ \\
Revised Aug $11^{\text {th }}, 2020$ \\
Accepted Sep $12^{\text {th }}, 2020$ \\
\hline
\end{tabular}

\section{Keyword:}

Hasil belajar

KPK

FPB

Pendekatan konstruktivisme

\begin{abstract}
Penelitian dilatarbelakangi rendahnya hasil belajar KPK dan FPB di kelas IV SDN 12 Sungai Liku Kecamatan Ranah Pesisir Kab. Pesisir Selatan. Siswa tidak diberi kesempatan untuk mengkomunikasikan pengetahuan awalnya dan membangun sendiri pemahamannya. Untuk mengatasinya, peneliti menerapkan Pendekatan Konstruktivisme untuk meningkatkan hasil belajar. Tujuan penelitian mendeskripsikan perencanaan, pelaksanaan, dan peningkatan hasil belajar KPK dan FPB di kelas IV SDN 12 Sungai Liku Kecamatan Ranah Pesisir Kab. Pesisir Selatan dengan pendekatan konstruktivisme. Jenis penelitian adalah Penelitian Tindakan Kelas menggunakan pendekatan kualitatif dan kuantitatif. Subjek penelitian guru dan 20 siswa kelas IV. Teknik pengumpulan data menggunakan observasi, tes, dokumentasi. Analisis data menggunakan analisis data kualitatif yaitu reduksi data, penyajian data, kesimpulan. Analisis data kuantitatif yaitu analisis deskriptif. Penelitian dilaksanakan II siklus. Setiap siklus terdiri dari perencanaan, pelaksanaan, pengamatan, refleksi. Hasil penelitian menunjukkan peningkatan dari siklus I ke siklus II, perencanaan pembelajaran dari $84 \%$ (baik) menjadi 94\%\% (sangat baik). Aktivitas guru dari 80\% (baik) menjadi $90 \%$ (sangat baik), aktivitas siswa dari $75 \%$ (cukup) menjadi $85 \%$ (baik). Hasil belajar aspek kognitif siswa dari 85\% (baik) menjadi 95\% (sangat baik), afektif dari 70\% (cukup) menjadi 85\% (baik), psikomotor dari $80 \%$ (baik) menjadi $90 \%$ (sangat baik). Dapat disimpulkan bahwa pendekatan konstruktivisme dapat meningkatkan hasil belajar KPK dan FPB di kelas IV SDN 14 Rantau Batu Ambacang Kec. Linggo Sari Baganti.
\end{abstract}

(C) 2020 The Authors. Published by IICET.

This is an open access article under the CC BY-NC-SA license (https://creativecommons.org/licenses/by-nc-sa/4.0

\section{Corresponding Author:}

Sabri Sabri,

SDN 12 Sungai Liku Kecamatan Ranah Pesisir Kab. Pesisir Selatan

Email: sabri@gmail.com

\section{Pendahuluan}

Selain itu pembelajaran kelipatan persekutuan terkecil dan faktor persekutuan terbesar (FPB) berfungsi menjumlahkan bilangan pecahan yang penyebutnya tidak sama dan memudahkan siswa menemukan bentuk bilangan pecahan paling sederhana.Menurut Akbar (1993:249) "salah satu kegunaan mencari kelipatan persekutuan terkecil (KPK) adalah untuk menjumlahkan bilangan pecahan yang penyebutnya tidak sama". Mengingat fungsi kelipatan persekutuan terkecil (KPK) memudahkan menjumlahkan pecahan yang penyebutnya tidak sama sehingga dapat memudahkan siswa menentukan hasil bilangan yang akan dicari. 
Agar pelajaran kelipatan persekutuan terkecil (KPK) dan faktor persekutuan terbesar (FPB) lebih optimal di SD guru harus berusaha menyajikan materi sebaik mungkin dengan melibatkan siswa secara langsung guru harus memilih pendekatan pembelajaran yang sesuai, agar siswa terlibat secara aktif selama proses pembelajaran, sehingga pembelajaran berlangsung secara efektif, dan efisien. Pembelajaran keliptan persekutuan terkecil (KPK) dan faktor persekutuan terbesar (FPB) di sekolah dasar idealnya dilaksanakan dengan mengikutkan siswa dalam proses pembelajaran sehingga siswa mengerti dengan konsep pembelajaran dan mudah mencari kelipatan persekutuan terkecil dari bilangan tersebut.

Berdasarkan pengalaman penulis mengajar di kelas IV UPT SDN 12 Sungai Liku Kecamatan Ranah Pesisir Kab. Pesisir Selatan, pada saat pembelajaran meteri kelipatan persekutuan terkecil (KPK) dan faktor persekutuan terbesar (FPB) ditemukan beberapa permasalahan, proses pembelajaran berpusat pada guru belum melibatkan siswa aktif dalam menemukan konsep kelipatan persekutuan terkecil (KPK) dan faktor persekutuan terbesar (FPB), dalam menyampaikan materi pelajaran, guru tidak mengaitkan dengan permasalahan yang kontektual atau tidak sesuai dengan pengalaman sehari-hari siswa. Sedangkan dari segi siswa yaitu, siswa kurang memahami konsep kelipatan persekutuan terkecil dan faktor persekutuan terbesar yang disebabkan oleh anak yang kurang mengerti dengan cara mencari kelipatan persekutuan terkecil (KPK) dan faktor persekutuan terbesar (FPB).

Hal ini dilihat dari hasil ulangan harian siswa semester I pada Pembelajaran kelipatan persekutuan terkecil (KPK) dan faktor persekutuan terbesar (FPB) di kelas IV UPT SDN 12 Sungai Liku Kecamatan Ranah Pesisir Kab. Pesisir Selatan. Berdasarkan tabel di atas terlihat rata nilai ulangan harian siswa mengenai KPK dan FPB dikelas IV UPT SDN 12 Sungai Liku Kecamatan Ranah Pesisir Kab. Pesisir Selatan 55\% tidak tuntas. Dimana 9 orang yang nilainya mencapai KKM yang ditetapkan dan 11 orang yang belum tuntas. Hal ini menunjukkan bahwa hasil belajar siswa pada pembelajaran Kelipatan Persekutuan Terkecil (KPK) dan faktor persekutuan terbesar (FPB) masih rendah.

Pendekatan kontruktivisme dapat meningkatkan hasil belajar siswa, hal ini didukung oleh penelitian Dewi (2007:4) yang mana penelitian tersebut berhasil memenuhi target ketuntasan siswa yang ingin dicapai yaitu $75 \%$ nilai siswa telah meningkat dengan nilai rata-rata 76,00 , jadi telah mencapai indikator keberhasilan. Dengan kata lain, penggunaan pendekatan kontruktivisme dapat meningkatkan hasil belajar siswa".

Berdasarkan uraian di atas, penulis tertarik untuk melakukan penelitian tentang "peningkatan hasil belajar kelipatan terkecil (KPK) dan faktor persekutuan terbesar (FPB) dengan pendekatan kontruktivisme di kelas IV UPT SDN 12 Sungai Liku Kecamatan Ranah Pesisir Kab. Pesisir Selatan".

\section{Metode}

Penelitian ini telah dilaksanakan di Kelas IV UPT SDN 12 Sungai Liku Kecamatan Ranah Pesisir Kab. Pesisir SelatanPesisir Selatan. Sebagai subjek dalam penelitian ini adalah siswa kelas IV, yang terdaftar pada semester I Tahun Pelajaran 2018/2019, dengan jumlah siswa 20 orang, 11 orang laki-laki dan 9 orang perempuan. Penelitian telah dilaksanankan pada tahun ajaran 2018/2019 di UPT SDN 12 Sungai Liku Kecamatan Ranah Pesisir Kab. Pesisir SelatanKabupaten Pesisir Selatan, Pelaksanaan tindakan terdiri dari dua siklus. Siklus I terdiri dari dua pertemuan, pertemuan pertama dilaksanakan pada hari Senin tanggal 09 September 2019, pertemuan kedua dilaksanakan pada tanggal 14 september 2019 dan siklus II terdiri dari satu kali pertemuan yang dilaksanakan pada tanggal 21 September 2019.

Penelitian yang dilakukan bertujuan untuk meningkatkan hasil belajaran kelipatan persekutan terkecil (KPK) dan faktor persekutuan terbesar (FPB) melalui pendekatan Kontruktivisme di kelas IV UPT SDN 12 Sungai Liku Kecamatan Ranah Pesisir Kab. Pesisir SelatanKabupaten Pesisir Selatan. Penelitian difokuskan pada perencanaan, pelaksanaan, dan penilaian proses pembelajaran dengan menggunakan pendekatan kualitatif dan kuantitatif. Jenis penelitian ini adalah Penelitian Tindakan Kelas (PTK).Menurut wardani, (2002:14) PTK "adalah penelitian yang dilakukan oleh guru didalam kelasnya sendiri melalui refleksi diri, dengan tujuan utama memperbaiki kinerjanya sebagai guru.Sehingga hasil belajar siswa menjadi meningkat".

Siklus penelitian ini mengikuti tahapan atau alur-alur penelitian tindakan kelas dalam suatu siklus. Dalam penelitian ini peneliti menggunakan model Kemmis dan Taggart (dalam Rita Wati 2007:27) "proses penilitian tindakan kelas merupakan proses daur ulang atau siklus yang di mulai dari aspek perencanaan, melakukan tindakan, melakukan observasi terhadap tindakan dan melakukan refleksi“.

Dalam penelitian tindakan kelas ini peneliti menggunakan dua siklus, siklus pertama dilakukan dua kali pertemuan, siklus kedua satu kali pertemuan dan setiap akhir pertemuan diadakan evaluasi untuk mengetahui hasil belajar siswa. Apabila siklus I belum berhasil maka akan dilanjutkan siklus ke II. Prosedur penelitian 
yang dilakukan yaitu, perencanaan, pelaksanaan tindakan, tahap pengamatan dan refleksi.Data penelitian berupa hasil pengamatan dan tes dari setiap tindakan perbaikan pembelajaran dengan menggunakan pendekatan kontruktivime untuk meningkatkan pemahaman siswa dalam pembelajaran kelipatan persekutuan terkecil (KPK) dan faktor persekutuan terbesar (FPB).

Analisis data yang akan digunakan dalam PTK ini adalah analisis kuantitatif dan kualitatif (Kunandar, 2008:123). Data yang dikumpulkan pada setiap kegiatan observasi dari pelaksanaan siklus PTK ini akan dianalisis secara deskriptif yang menggunakan tekhnik persentase untuk melihat kecendrungan yang terjadi dalam kegiatan pembelajaran.

Kriteria Ketuntasan minimal (KKM) pembelajaran kelipatan persekutuan terkecil (KPK) dan faktor perseutuan terbesar (FPB) dengan pendekatan Kontruktivisme di kelas IV UPT SDN 12 Sungai Liku Kecamatan Ranah Pesisir Kab. Pesisir Selatantahun pelajaran 2018/2019 di tetapkan 70, jika KKM tidak tercapai pada Siklus I, maka diteruskan pada Siklus II sampai berhasil mencapai KKM.

\section{Hasil dan Pembahasan}

\section{Hasil Penelitian}

Penelitian ini dilaksanakan di kelas IV UPT SDN 12 Sungai Liku Kecamatan Ranah Pesisir Kab. Pesisir Selatanpada materi kelipatan persekutuan terkecil (KPK) dan faktor persekutuan terbesar (FPB) semester I tahun pelajaran 2018/2019. Dalam pelaksanaan tindakan dibagi menjadi dua siklus dimana siklus I terdiri dari dua dua kali pertemuan dan siklus II satu kali pertemuan. Peneliti berkaloborasi dengan teman sejawat sebagai obsever I, sedangkan peneliti sebagai guru praktisi.

\section{Siklus I Pertemuan I}

\section{Perencanaan Pembelajaran}

Rencana pelaksanaan pembelajaran yang akan dilaksanakan terdiri dari standar kompetensi yang ingin dicapai adalah "memahami dan menggunakan faktor dan kelipatan dalam pemecahan masalah". Dan kompetensi dasarnya adalah menentukan kelipatan persekutuan terkecil (KPK) dan faktor persekutuan terbesar (FPB) sedangan indikator yang ingin dicapai adalah 1)Menentukan kelipatan persekutuan dari 2 bilangan dengan garis bilangan 2)Menyelesaikan kelipatan persekutuan terkecil dari 2 bilangan dengan faktorisasi prima 3)menentukan kelipatan persekutuan terkecil dari 2 bilangan dengan tabel pembagian .

Untuk mencapai indikator Diatas, perencanaan pembelajaran dibagi dalam tiga tahap pembelajaran yaitu tahap awal 10 menit, tahap inti 40 menit, dan akhir 20 menit. Agar indikator tersebut tercapai dengan sempurna maka pembelajaran matematika dilaksanakan dengan menggunakan pendekatan kontruktivisme. Setelah itu ditutup dengan melakukan penilaian.

\section{Pelaksanaan pembelajaran}

\section{Kegiatan awal}

Pembelajaran diawali dengan menggucapkan salam, kemudian mempersiapkan hal-hal yang dibutuhkan dalam pelajaran. Mengkondisikan kelas yaitunya dengan merapikan tempat duduk, mengapsen siswa, berdoa sebelum belajar, setelah itu peneliti melakukan apersepsi yang tujuannya untuk membangkitkan schemata siswa terhadap materi yang akan diajarkan.

\section{Kegiatan inti}

1) Pada tahap pengaktifan pengetahuan yang sudah ada, guru memperlihatkan pipet dan kelereng, siswa dilibatkan dalam menggunakan pipet dan kelereng dan bertanya jawab kelipatan suatu bilangan; 2) Pada tahap pemerolehan pengetahuan baru, guru memberikan setiap kelompok LKS tentang KPK, meminta siswa membaca LKS dan mencoba memahami cara mengerjakan LKS; 3) Pada tahap pemahaman pengetahuan, guru meminta siswa terlebih dahulu untuk berdiskusi dan menyajikan kelipatan suatu bilangan dan menentukan KPK yang telah dikerjakan dengan kelompoknya, setelah itu meminta kelompok lain memberi tanggapan terhadap hasil diskusi kelompok yang tampil; 4) Pada tahap menerapkan pengetahuan dan pengalaman yang telah diperoleh, siswa mengerjakan contoh soal yang telah diberikan oleh guru, dan guru memperhatikan seluruh siswa yang sedang mengerjakan latihan, dan setelah selesai, barulah siswa dan guru membahas cara menentukan KPK; 5) Pada tahap melakukan refleksi, siswa dan guru bertanya jawab tentang cara menentukan KPK dengan menggunakan pipet, dan siswa mencatat penjelasan guru tentang KPK.

\section{Kegiatan akhir}

Pada kegiatan akhir ini, guru memberikan kesempatan kepada siswa untuk bertanya terhadap materi yang belum dimengerti dan membimbing siswa untuk menyimpulkan materi pelajaran. Setelah itu, barulah guru 
memberikan tindak lanjut berupa meminta siswa mengerjakan soal latihan dan memberikan tugas rumah kepada siswa.

\section{Pengamatan}

\section{Pengamatan rencana pelaksanaan pembelajaran}

Berdasarkan hasil penilaian obsever terhadap kemampuan guru merancang pembelajaran pada pertemuan pertama siklus I, jumlah skor yang diperoleh adalah 25 dari jumlah skor maksimal 32, dengan demikian skor yang diperoleh $78 \%$ dapat dilihat pada lampiran 7 halaman 111. Hal ini menunjukkan kemampuan guru merancang pembelajaran termasuk kategori baik.

\section{Pelaksanaan pembelajaran}

Secara umum, ketercapain semua tahapan pelaksanaan pendekatan kontruktivismedalam pembelajaran kelipatan persekutuan terkecil (KPK) bagi siswa kelas IV UPT SDN 12 Sungai Liku Kecamatan Ranah Pesisir Kab. Pesisir Selatanbelum tercapai. Hal ini terlihat dari hasil analisis kegiatan pembelajaran dari aspek guru mendapatkan skor $65 \%$.

\section{Analisis kegiatan siswa}

Fokus kegiatan siswa dalam pembelajaran adalah kesiapan siswa dalam menerima pembelajaran, menjelaskan topik-topik pembelajaran. Menyebutkan pesan yang disimak, menyimak guru dan mendengarkan penjelasan guru, dan melakukan permainan bisik berantai.

Secara umum, ketercapain semua tahapan pelaksanaan pendekatan kontruktivisme dalam pembelajaran kelipatan persekutuan terkecil (KPK) bagi siswa kelas IV UPT SDN 12 Sungai Liku Kecamatan Ranah Pesisir Kab. Pesisir Selatanbelum tercapai. Hal ini terlihat dari hasil analisis kegiatan pembelajaran dari aspek siswa mendapatkan skor $75 \%$

\section{Hasil belajar}

Hasil belajar yang diperoleh siswa setelah melakukan evaluasi jika ditinjau dari segi penilain kognitif pada siklus I pertemuan I yaitu 50\% dengan kualifikasi kurang, dan hasil penilain afektif yang didapat pada siklus I pertemuan I ini adalah 50\% dengan kualifikasi cukup sedang untuk penilain psikomotor dengan menggunakan pendekatan kontruktivisme nilai yang didapat adalah $55 \%$.

Secara keseluruhan hasil pembelajaran dengan menggunakan pendekatan kontruktivisme pada pembelajaran kelipatan persekutuan terkecil (KPK) di kelas IV UPT SDN 12 Sungai Liku Kecamatan Ranah Pesisir Kab. Pesisir Selatanpada siklus I pertemuan I adalah 60\% dengan kualifikasi kurang sesuai dengan pendapat Suharsimi.

\section{Refleksi}

Hasil belajar yang diperoleh siswa setelah melakukan evaluasi jika ditinjau dari segi penilain kognitif pada siklus I pertemuan I yaitu 65\% dapat dilihat pada lampiran 4 halaman 106 dengan kualifikasi kurang, dan hasil penilain afektif yang didapat pada siklus I pertemuan I ini adalah $50 \%$ dengan kualifikasi cukup, sedangkan untuk penilain psikomotor dengan menggunakan pendekatan kontruktvismenilai yang didapat adalah $55 \%$.

Secara keseluruhan hasil pembelajaran dengan menggunakan pendekatan kontruktivisme pada pembelajaran kelipatan persekutuan terkecil (KPK) di kelas IV UPT SDN 12 Sungai Liku Kecamatan Ranah Pesisir Kab. Pesisir Selatanpada siklus I pertemuan I adalah 40\% dengan kualifikasi kurang.

\section{Siklus I Pertemuan II}

\section{Perencanaan Pembelajaran}

Penggunaan pendekatan kontruktivisme dalam pembelajaran faktor persekutuan terbesar (FPB) disusun dan disajikan dalam bentuk rencana pelaksanaan pembelajaran. Rencana pelaksanaan pembelajaran ini disusun oleh peneliti berkolaborasi dengan observer, yaitu guru kelas IV UPT SDN 12 Sungai Liku Kecamatan Ranah Pesisir Kab. Pesisir Selatan. Rencana pelaksanaan pembelajaran disusun berdasarkan kurikulum KTSP 2006 dan program semester I tahun pelajaran 2018/2019.

Rencana pelaksanaan pembelajaran yang akan dilaksanakan terdiri dari standar kompetensi yang ingin dicapai adalah "memahami dan menggunakan faktor dan kelipatan dalam pemecahan masalah". Dan kompetensi dasarnya adalah "menentukan kelipatan persekutuan terkecil (KPK) dan faktor persekutuan terbesar (FPB)" sedangan indikator yang ingin dicapai adalah 1) Menentukan faktor persekutuan dari 2 bilangan 2)Menyelesaikan soal-soal faktor persekutuan terbesar dari 2 bilangan.

Hasil belajar akan tercermin dalam indikator-indikator tersebut, agar indikator tercapai, maka pembelajaran dilaksanakan dengan menggunakan pendekatan kontruktivisme dalam proses pembelajaran. 
Materi pembelajaran yang akan dilaksanakan pada pertemuan II siklus I ini adalah faktor persekutuan terbesar, kegiatan pembelajaran akan dilaksanakan dalam tiga tahapan utama, yaitu kegiatan awal, kegiatan inti, dan kegiatan akhir. Media yang dipakai dalam pembelajaran ini adalah spidol, papan tulis, penghapus papan, dan pipet. Penilain pembelajaran yang digunakan adalah penilain tes berupa esay (uraian).

\section{Pelaksanaan pembelajaran}

Berdasarkan hasil penilaian obsever terhadap kemampuan guru merancang pembelajaran pada pertemuan kedua siklus I, jumlah skor yang diperoleh adalah 27 dari jumlah skor maksimal 32, dengan demikian skor yang diperoleh $84 \%$ dengan kualifikasi baik.

\section{Pelaksanaan pembelajaran}

Secara umum, ketercapain semua tahapan pelaksanaan pendekatankontruktivisme dalam pembelajaran faktor persekutuan terbesar (FPB) bagi siswa kelas IV UPT SDN 12 Sungai Liku Kecamatan Ranah Pesisir Kab. Pesisir Selatansudah tercapai. Hal ini terlihat dari hasil analisis kegiatan pembelajaran dari aspek guru mendapatkan skor $80 \%$ dengan kualifikasi baik.

\section{Analisis kegiatan siswa.}

Secara umum, ketercapain semua tahapan pelaksanaan pendekatan kontruktivisme dalam pembelajaran faktor persekutuan terbesar (FPB) bagi siswa kelas IV UPT SDN 12 Sungai Liku Kecamatan Ranah Pesisir Kab. Pesisir Selatan sudah baik. Hal ini terlihat dari hasil analisis kegiatan pembelajaran dari aspek siswa mendapatkan skor $75 \%$ dengan kualifikasi baik.

\section{Hasil belajar}

Hasil belajar yang diperoleh siswa setelah melakukan evaluasi jika ditinjau dari segi penilain kognitif pada siklus I pertemuan II yaitu 85\% dapat dilihat pada lampiran 14 halaman 129 dengan kualifikasi baik, dan hasil penilain afektif yang didapat pada siklus I pertemuan II ini adalah 70\% dengan kualifikasi cukupsedangkan untuk penilain psikomotor dengan menggunakan pendekatan kontruktivis mepersentase ketuntasan yang diperoleh adalah 80\% dapat dilihat pada lampiran 16 halaman 132 dengan kualifikasi baik.

Secara keseluruhan hasil pembelajaran dengan menggunakan pendekatan kontruktivisme pada pembelajaran faktor persekutuan terbesar (FPB) di kelas IV UPT SDN 12 Sungai Liku Kecamatan Ranah Pesisir Kab. Pesisir Selatanpada siklus I pertemuan II adalah 70\% dapat dilihat pada lampiran 20 halaman 141 dengan kualifikasi baik.

\section{Refleksi}

Hasil pembelajaran dengan menggunakan pendekatan kontruktivisme pada pembelajaran faktor persekutuan terbesar (FPB) di kelas IV UPT SDN 12 Sungai Liku Kecamatan Ranah Pesisir Kab. Pesisir Selatan pada siklus I pertemuan II adalah 75\% dapat dilihat pada lampiran 20 halaman 141. Sesuai dengan pendapat BSNP (2006:12) "pembelajaran dikatakan berhasil apabila standar ketuntasan belajar dari kelas mencapai 75\%" hal ini menyatakan bahwa hasil belajar siswa pada siklus I pertemuan II ini sudah dapat dikatakan berhasil, Untuk selanjutnya diharapkan agar hasil belajar yang dicapai siswa dapat meningkat lebih baik lagi. Dan untuk siklus ke II dapat dilanjutkan dengan kelipatan persekutuan terkecil (KPK) dan faktor persekutuan terbesar (FPB).

\section{Siklus II}

Berdasarkan hasil penilaian obsever terhadap kemampuan guru merancang pembelajaran pada pertemuan kedua siklus II, jumlah skor yang diperoleh adalah 30 dari jumlah skor maksimal 32, dengan demikian skor yang diperoleh dalam penyususnan RPP siklus II adalah 94\%.

\section{Pelaksanaan pembelajar}

Secara umum, ketercapain semua tahapan pelaksanaan pendekatan kontruktivisme dalam pembelajaran kelipatan persekutuan terkecil (KPK) dan faktor persekutuan terbesar (FPB) bagi siswa kelas IV UPT SDN 12 Sungai Liku Kecamatan Ranah Pesisir Kab. Pesisir Selatan sudah tercapai. Hal ini terlihat dari hasil analisis kegiatan pembelajaran dari aspek guru mendapatkan skor 94\% dengan kualifikasi sangat baik.

\section{Analisis kegiatan siswa}

Secara umum, ketercapain semua tahapan pelaksanaan pendekatan kontruktivisme dalam pembelajaran kelipatan persekutuan terkecil ( KPK) dan faktor persekutuan terbesar (FPB) bagi siswa kelas IV UPT SDN 12 Sungai Liku Kecamatan Ranah Pesisir Kab. Pesisir Selatan sudah tercapai. Hal ini terlihat dari hasil analisis kegiatan pembelajaran dari aspek siswa mendapatkan skor $85 \%$ dengan kualifikasi sangat baik. 


\section{Hasil belajar}

Hasil belajar yang diperoleh siswa setelah melakukan evaluasi jika ditinjau dari segi penilain kognitif pada siklus II yaitu 95\% dapat dilihat pada lampiran 24 halaman 149 dengan kualifikasi sangat baik, dan hasil penilain afektif yang didapat pada siklus II ini adalah $85 \%$ dapat dilihat pada lampiran 25 halaman 150 dengan kualifikasi baik sedangkan untuk penilain psikomotor dengan menggunakan pendekatan kontruktivisme nilai yang didapat adalah $90 \%$ dapat dilihat pada lampiran 26 halaman 152 dengan kualifikasi sangat baik.

Secara keseluruhan hasil pembelajaran dengan menggunakan pendekatan kontruktivisme pada pembelajaran kelipatan persekutuan terkecil (KPK) dan faktor persekutuan terbesar (FPB) di kelas IV UPT SDN 12 Sungai Liku Kecamatan Ranah Pesisir Kab. Pesisir Selatan pada siklus II adalah 80\% dengan kualifikasi baik.

\section{Refleksi}

Hasil pembelajaran dengan menggunakan pendekatan kontruktivisme pada pembelajaran kelipatan persekutuan terkecil (KPK) dan faktor persekutuan terbesar (FPB) di kelas IV UPT SDN 12 Sungai Liku Kecamatan Ranah Pesisir Kab. Pesisir Selatanpada siklus II adalah $80 \%$. Sesuai dengan pendapat BSNP (2006:12) "pembelajaran dikatakan berhasil apabila standar ketuntasan belajar dari kelas mencapai 75\%" hal ini menyatakan bahwa hasil belajar siswa pada siklus II ini sudah berhasil dengan sangat baik.

\section{Pembahasan}

\section{Perencanaan}

Berdasarkan hasil penilain observer terhadap kemampuan guru merancang rencana pelaksanaan pembelajaran pada pertemuan I siklus I jumlah skor yang diperoleh $78 \%$, hal ini menunjukkan kemampuan guru merancang pembelajaran termasuk kategori baik.dan pada pertemuan ke dua, siklus I jumlah skor yang diperoleh adalah $84 \%$ dengan kualifikasi baik, hal ini menunjukkan kemampuan guru dalam merancang pembelajaran termasuk kategori baik.

Pada siklus II rancangan pelaksanaan pembelajaran yang dibuat bernilai 94\% dengan kualifikasi sangat baik, karena hanya satu deskriptor yang belum muncul pada rencana pelaksanaan pembelajaran yang dibuat.

\section{Hasil belajar}

Hasil belajar adalah hasil yang diperoleh siswa pada waktu proses pembelajaran dan setelah proses pembelajaran. Hasil belajar yang diperoleh siswa pada siklus I pertemuan I dari aspek kognitif ini adalah $60 \%$, dengan kualifikasi kurang dan hasil belajar dari aspek kognitif yang dapat dicapai siswa pada siklus I pertemuan ke II adalah $85 \%$, dengan kualifikasi baik.

Hasil belajar yang diperoleh siswa pada siklus I pertemuan I dari aspek afektif adalah $50 \%$, dengan kualifikasi cukup dan hasil belajar dari aspek afektif yang dapat dicapai siswa pada siklus I pertemuan ke II adalah $70 \%$, dengan kualifikasi cukup.

Hasil belajar adalah hasil yang diperoleh siswapada waktu proses pembelajaran dan setelah proses pembelajaran. Hasil belajar yang diperoleh siswa pada siklus II dari aspek kognitif ini adalah $95 \%$, dengan kualifikasi sangat baik.

Hasil belajar yang diperoleh siswa pada siklus II dari aspek afektif adalah $85 \%$, dengan kualifikasi baik. Aspek psikomotor adalah 90\%, dengan kualifikasi sangat baik.

Hasil belajar yang diperoleh siswa pada siklus I pertemuan I dari aspek psikomotor adalah 55\%, dengan kualifikasi cukup dan hasil belajar dari aspek psikomotor yang dapat dicapai siswa pada siklus I pertemuan ke II adalah $80 \%$, dengan kualifikasi baik.

Secara umum hasil belajar siswa dari sebelum proses pembelajaran dimulai dan setelah proses belajar dimulai dan setelah proses pembelajaran dengan menggunakan pendekatan kontruktivisme, masih banyak kekurangan yang perlu diperbaiki, untuk memperbaiki kekurangan yang terjadi maka peneliti melanjutkan ke siklus ke II sebagai bahan perbandingan untuk mengetahui apakah pendekatan kontruktivisme dapat meningkatkan hasil belajar siswa pada pembelajaran KPK dan FPB.

Dan pada siklus ke II secara umum hasil pembelajaran KPK dan FPB dengan menggunakan pendekatan kontruktivisme dapat meningkatkan hasil belajar siswa. Hal ini dapat dibuktikan dengan nilai keberhasilan pembelajaran KPK dan FPB adalah 90\% dengan kualifikasi sangat baik. Hal ini membuktikan bahwa pendekatan kontruktivisme dapat meningkatkan hasil belajar siswa. 


\section{Simpulan}

Berdasarkan hasil penelitian dan pembahasan di atas, siklus I dan II dapat disimpulkan beberapa hal sebagai berikut : 1) Rencana pelaksanaan pembelajaran dengan penggunaan pendekatan kontruktivisme dalam pembelajaran kelipatan persekutuan terkecil (KPK) dan faktor persekutuan terbesar (FPB) di kelas IV UPT SDN 12 Sungai Liku Kecamatan Ranah Pesisir Kab. Pesisir Selatan Kabupaten Pesisir Selatan, dapat dibuat dengan mengikuti langkah-langkah pendekatan kontruktivisme, pada siklus I kemampun guru dalam merancang pembelajaran dengan persentase $84 \%$ kategori baik, dan Siklus II mencapai tingkat persentase $94 \%$ dengan kategori sangat baik; 2) Pelaksanaan pembelajaran kelipatan persekutuan terkecil (KPK) dan faktor persekutuan terbesar (FPB) siklus I dan II dengan penggunaan pendekatan kontruktivismedi kelas IV UPT SDN 12 Sungai Liku Kecamatan Ranah Pesisir Kab. Pesisir SelatanKabupaten Pesisir Selatan telah dilaksanakan sesuai dengan perencanaan.Pada siklus I pelaksanaan kegiatan guru $80 \%$ dan pada siklus II meneningkat menjadi $90 \%$, dan pada aktivitas siswa pada siklus I persentasenya adalah $75 \%$ dan pada siklus II mencapai peningkatan menjadi 89 \% dengan kualifikasi sangat baik; 3) Hasil belajar siswa setelah penerapan pendekatan kontruktivisme dari siklus I dan siklus II yaitu siklus I Pertemuan I sebesar $70 \%$, siklus I Pertemuan II sebesar $75 \%$, Siklus II sebesar 85\%. Dari data tersebut terlihat bahwa nilai siswa tidak tetap, dimana setiap siklus meningkat. Penggunaan pendekatan kontruktivismepada pembelajaran kelipatan persekutuan terkecil (KPK) dan faktor persekutuan terbesar (FPB) bagi siswa kelas IV UPT SDN 12 Sungai Liku Kecamatan Ranah Pesisir Kab. Pesisir Selatan Kabupaten Pesisir Selatan telah dapat meningkatkan hasil belajar siswa. Hal ini terlihat dari terwujudnya hasil belajar kelipatan persekutuan terkecil (KPK) dan faktor persekutuan terbesar (FPB) yang sesuai dengan KKM yang telah ditetapkan. Disarankan kepada pihak sekolah supaya bisa melengkapi buku sumber dan media-media pendukung dalam pembelajaran.

\section{Referensi}

Arikunto Suhaimi, dkk. (2008). Pendidikan Tindakan Kelas. Jakarta : Bumi Aksara.

Arikunto Suhaimi, dkk. (2008). Evaluasi Program Pendidikan. Jakarta : Bumi Aksara.

Cahyo Agus. (2013). Aplikasi teori-teori Belajar Mengajar. Jokjakarta : Diva press.

Depdiknas. (2006). Kurikulum Tingkat Satuan Pendidikan Jenjang Pendidikan Dasar. Jakarta : Depdiknas.

Hakim Lukmanul. (2012). Perencanaan Pembelajaran.Bandung: CV. Wacana Prima.

Hamalik Oumar. (2008). Proses Belajar Mengajar. Jakarta : Bumi Aksara.

Kunandar. (2007). Guru Profesional Implementasi Kurikulum Tingkat Satuan Pendidikan Jenjang Pendidikan (KTSP) dan Sukses dalam Sertifikasi Guru. Jakarta :PT Raja Grafindo Persada.

Miles Matthew B, dan Buherman A. Michael . (1992). Analisis Data Kualitatif. Jakarta : Universitas Indonesia Press.

Mucthar. (2003). Matematika. Jakarta: Yudisthira.

Muhamad Nur dan Prima Retno Wikandari. (2000). Pengajaran Berpusat Pada Siswa dan Pendekatan Kontrutivis dalam Pengajaran. Surabaya: Universitas Negeri Surabaya.

Mustaqim Burhan dan Ary Astuti. (2008). Ayo Belajar Matematika. Jakarta : CV Buana Raya.

Purwanto Ngalim. (2006). Prinsip-Prinsip dan Teknik Evaluasi Mengajar. Bandung : PT. Remaja Rosdakarya.

Nurhadi. (2003). Pembelajaran Kontekstual (Contexstual theacing and Learning)CTL dan Penerapannya dalam KBK. Malang : Universitas Negeri Malang.

Pujiati, dkk. (2011). Pembelajaran Faktor Persekutuan Terbesar dan Kelipatan Persekutuan Terkecil di SD. Yokyakarta: Kementerian Pendidikan Nasional 